\title{
9- Effect of Bayfolan copper on the control of Pseudomonas syringae pv. garcae in vitro
}

Amanda Pereira Honório ${ }^{1}$

Roseli dos Reis Goulart ${ }^{2}$

Eunice Maria Baquião 3

One of the limiting factors in coffee production is the aureolated spot caused by the bacterium Pseudomonas syringae pv. garcae. This work aimed to evaluate different Bayfolan ${ }^{\circledR}$ copper concentrations in the growth of two isolates of $P$. syringae pv. garcae in vitro. P. syringae pv. garcae 157 and 59 isolates were used. Two experiments were carried out in a completely randomized design (CRD) with 7 treatments and 5 replications, in a total of 35 experimental units. Each experimental

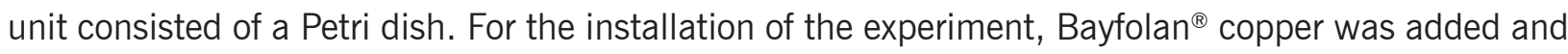
homogenized into Kado 523 culture medium at concentrations of $0 ; 625 ; 1.250 ; 1.875 ; 2.500$ and 3.000 ppm, and as positive control the product Kasumin ${ }^{\circledR}$ was used at 3.000 ppm concentration. Bayfolan ${ }^{\circledR}$ copper reduced the growth of the two isolates evaluated in vitro with increasing concentration. At concentrations of 2.500 and 3.000 ppm, Bayfolan ${ }^{\circledR}$ copper inhibited completely the growth of both isolates, similarly to the Kasumin ${ }^{\circledR}$ treatment. The research reveals that Bayfolan ${ }^{\circledR}$ copper is efficient to control $P$. syringae pv. garcae in vitro from concentrations of 2.500 ppm onwards.

Keywords: Bacteriosis. Copper sulphate. Coffea arabica.

\section{Introduction}

Coffee is one of the most economically and socially important crops for Brazilian agriculture, with southern Minas Gerais being the largest producing region. Brazil is responsible for one third of the world's coffee production, which makes it the world's largest producer (CONAB, 2017).

However, pests and different disease-causing pathogens such as fungi and bacteria, which may also compromise the quality of the beans and the beverage, can jeopardize coffee production. The aureolated spot caused by the bacterium Pseudomonas syringae pv. garcae (AMARAL; TEIXEIRA; PINHEIRO, 1956), discovered for the first time in the city of Graça, state of São Paulo (AMARAL; TEIXEIRA; PINHEIRO, 1956), is one of the main bacteriosis affecting coffee (OLIVEIRA, 2017).

According to Rodrigues et al. (2013), the bacterium is gram negative, with straight or slightly curved rod-shaped cells, measuring from 0.5-1.0x 1.5-4.0 $\mu \mathrm{m}$, movable through one to seven polar flagella, belonging to Phylum Proteobacteria, Class Gamma Proteobacteria, Order Pseudomonadales, Family Pseudomonadaceae, Genus Pseudomonas, Species P. syringae, Patovar garcae.

1 Instituto Federal de Educação, Ciência e Tecnologia do Sul de Minas Gerais - Campus Muzambinho, graduada em Engenharia Agronômica e Ciências Biológicas. amandanr97@gmail.com. Travessa José Valentino da Cruz, 54, Centro, Viçosa/MG, Cep: 36570-089.

2 Instituto Federal de Educação, Ciência e Tecnologia do Sul de Minas Gerais - Campus Muzambinho, docente. roseli.goulart@muz.ifsuldeminas.edu.br.

3 Instituto Federal de Educação, Ciência e Tecnologia do Sul de Minas Gerais - Campus Muzambinho, graduada em Engenharia Agronômica. eunicebachiaonr@gmail.com. 
The initial symptoms are irregular, yellowish, soggy lesions that progress to tissue necrosis. The area of necrotic tissue progresses over time, developing a yellow colored halo around the lesions. The plants may present necrosis and dry rot, both in their orthotropic and plagiotropic branches (BELAN, 2014). The bacterium promotes lesions on inflorescences, rosettes and new fruits (PATRÍCIO, 2011).

According to Rodrigues et al. (2013), bacteriosis mainly attacks seedlings, pruned coffee plantations and 3 to 4-year-old growing crops.

$P$. syringe pv. garcae spreads through coffee in rainy periods with mild temperatures. The occurrence of hail in the crop favors the occurrence of the bacterium, because, besides promoting leaf wetness, they cause wounds that act as entry ports for the bacterium. Crops located at high altitudes have the highest incidence of the disease due to wind action (RODRIGUES et al., 2013).

Cultural management of the disease should be started before crop formation, such as choosing the area to be implanted, which should be far from areas contaminated with the bacterium (RODRIGUES et al., 2013), and the formation of windbreaks around the crop, which can interfere with the speed the wind hits the plants and prevent pathogen scatter in rainy weather, should be considered (RODRIGUES et al., 2013).

For the chemical control of this bacteriosis, few products are available in the Phytosanitary Pesticide System (AGROFIT, 2019) such as copper oxychloride fungicide and Kasugamycin antibiotic. However, this type of treatment should be performed before the plant is infected, thus acting as a preventive, for greater protection of the plant and lower rates of the disease (PATRíCIO, 2008).

Therefore, producers have experienced significant economic losses, since the increased number of applications with bactericides and fungicides has increased the production costs (PETEK et al., 2006). Thus, significant changes have taken place in Brazilian coffee growing in order to achieve a more self-sustainable cultivation system, in which coffee grower profitability increases and environmental contamination is reduced (PETEK et al., 2006).

In this sense, an important factor is the nutritional management of the plant, as nutritionally balanced plants are less affected by diseases, due to nutrients play important roles in plant metabolism, influencing their growth, plant production and also the increased resistance to pathogens (ZAMBOLIM; VENTURA, 1993).

Nutrients may increase plant resistance to pathogens, because they are involved in changes in cell anatomy, such as thicker, lignified or silicified epidermis cells (ZAMBOLIM; VENTURA, 1993).

Among micronutrients, copper deserves attention, as it contributes to respiratory enzymes and photosynthesis. It increases the resistance of plants to diseases, enhancing their vigor, moreover, it seems to be related to hormones, since there is a decreasing fall of flowers, leaves and fruits (MALAVOLTA; GOMES; ALCARDE, 2000).

Erwinia amylovora (Burril) resistant apple leaves showed a large amount of copper. Potato resistance to late blight by Phytophthora infestans (Mont.) de Bary would be due to the increased activity of the enzyme peroxidase, caused by the use of copper on the leaves (ZAMBOLIM; VENTURA, 1996).

Several studies have proven the effectiveness of copper in vitro as a bactericide. Santos et al. (2010) observed that copper oxychloride and Soil-Set ${ }^{\circledR}$, a sulphur, copper, iron, manganese and zinc foliar fertilizer (ALLTECH, 2019), inhibited the growth of Xanthomonas campestris pv. viticola (Nayadu) in vitro, and the bactericidal action of Soil-Set ${ }^{\circledR}$ was possibly due to the presence of copper in its formulation.

Yamada (2014) concluded that isolates of $P$. siringae pv. garcae showed sensitivity to copper sulphate in vitro and that cuprous oxide preventively applied showed greater efficacy in controlling aureolated spot in coffee seedlings. 
Other studies also proved the efficiency of copper in vitro. Morais et al. (2015) reported that concentrations of copper hydroxide $(0.18 ; 0.36 ; 0.54$ and $0.72 \%)$ and copper phosphite $(0.83 \%)$ completely inhibited the growth of $P$. syringae pv. garcae in vitro.

According to Domingues et al. (2015), products formulated with copper hydroxide promoted a drastic reduction in the number of CF of $P$. syringae pv. garcae from the dose of $100 \mu \mathrm{g}$ a.i. per liter of N.A. medium.

Leaf fertilizers containing other elements associated with copper have often been commercially available, such as Bayfolan ${ }^{\circledR}$ copper.

Bayfolan ${ }^{\circledR}$ Copper is a foliar fertilizer composed of nitrogen, amino acids and associated copper sulphate that act together activating enzyme systems in plants (BAYER, 2017). Amino acids facilitate the penetration, assimilation and movement of nutrients within the plant, improving its activity and providing a nutritive effect, thus making the plants healthier and more productive. Its composition has total organic carbon 10.0\% (123.0 g L-1), nitrogen (water soluble) 3.0\% (36.9 $\mathrm{g} \mathrm{L}^{-1}$ ), copper (water soluble) $5.0 \%$ (61.5 $\mathrm{g} \mathrm{L}^{-1}$ ), and physical nature (fluid) (BAYER, 2017).

Therefore, the objective of this study was to evaluate the effect of different concentrations of Bayfolan ${ }^{\circledR}$ copper on the control of $P$. syringae pv. garcae in vitro.

\section{Material and methods}

The experiments were carried out at the Phytopathology Laboratory of the Federal Institute of Education, Science and Technology of Southern Minas Gerais - Campus Muzambinho.

The isolates of $P$. syringae pv. garcae used in the experiments were obtained from the Bacteriology Laboratory of the Federal University of Lavras, coming from coffee leaves from naturally infected fields, located in Lavras, southern region of Minas Gerais State. The pathogenicity of the isolate was confirmed in coffee seedlings under greenhouse conditions of the UFLA Department of Phytopathology.

For inoculum preparation, the seeding of the bacterium from both isolates was done in Kado and Heskett's 523 medium (1970). After 48 hours, the bacterial cells were suspended in sterile saline $(0.85 \% \mathrm{NaCl})$ in autoclave and the bacterial concentration determined in a $600 \mathrm{~nm}$ spectrophotometer (OD600), as described by Oliveira and Romeiro (1990). By dilution in sterile saline solution, a bacterial cell suspension of $1.1 \times 10^{8}$ dilution was prepared.

Two experiments were installed, and each one used a different isolate from $P$. syringae pv. garcae (157 and 59). The experiments were installed in a completely randomized design, and seven treatments with five replications were evaluated, in a total of 35 experimental units each. Each experimental unit consisted of a Petri dish.

Bayfolan ${ }^{\circledR}$ copper was added to a culture medium 523 at approximately $40^{\circ} \mathrm{C}$, at the following concentrations: $0 ; 0.63 ; 1.25 ; 1.88 ; 2.5 ; 3.0 \mathrm{~mL} \mathrm{~L}^{-1}$ of water, corresponding to $0,625,1.250$, $1.875,2.500$ and 3.000 ppm. As absolute control, a plate containing medium 523 (negative control) was used, as well as plates plus Kasugamycin antibiotic (Kasumin ${ }^{\circledR}-98 \%$ i.a) (positive control) at a concentration of $3.000 \mathrm{ppm}$. Subsequently, the medium was poured into a $9.0 \mathrm{~cm}$ diameter Petri dish.

After its solidification, $100 \mu \mathrm{L}$ of the inoculum suspension $\left(1.1 \times 10^{8} \mathrm{CFUmL}^{-1}\right)$ was added to each plate, distributed on the medium with the aid of a Drigalski loop. The plates were then kept incubated in B.O.D at $28 \pm 2{ }^{\circ} \mathrm{C}$ and a12-hour light photoperiod. 
To verify the efficiency of the treatments in relation to the inhibition of bacterial development, after 48 hours of incubation, the number of colony-forming units (CFU) developed in each plate was quantified.

The results were submitted to normality and homogeneity tests, through the GENES ${ }^{\circledR}$ program (CRUZ, 2001) and to the analysis of variance and regression, and the means compared by the ScottKnott test at the $5 \%$ significance level, through the SISVAR ${ }^{\circledR}$ program (FERREIRA, 2011).

\section{Results and discussion}

In general, both isolates of $P$. syringae pv. garcae showed significant reduction in CFU number with increasing Bayfolan ${ }^{\circledR}$ copper concentration, evidencing the bactericidal effect of the product.

For bacterial isolate 157 (FIGURE 1), at 630 ppm concentration of Bayfolan ${ }^{\circledR}$ copper, the number of CFU tended to increase. At 1.250 and 1.875 ppm concentrations of Bayfolan ${ }^{\circledR}$ copper, the number of colonies compared to the control reduced $15.91 \%$ and $54.55 \%$, respectively. From a concentration of $2.500 \mathrm{ppm}$, Bayfolan ${ }^{\circledR}$ copper completely inhibited bacterial growth in vitro.

Figure 1 - Effect of different concentrations of Bayfolan ${ }^{\circledR}$ copper on the growth of Pseudomonas syringae pv. garcae in vitro, Isolated 157, Muzambinho, 2018. Data transformed for $y=\sqrt{ }(x+0.5)$.

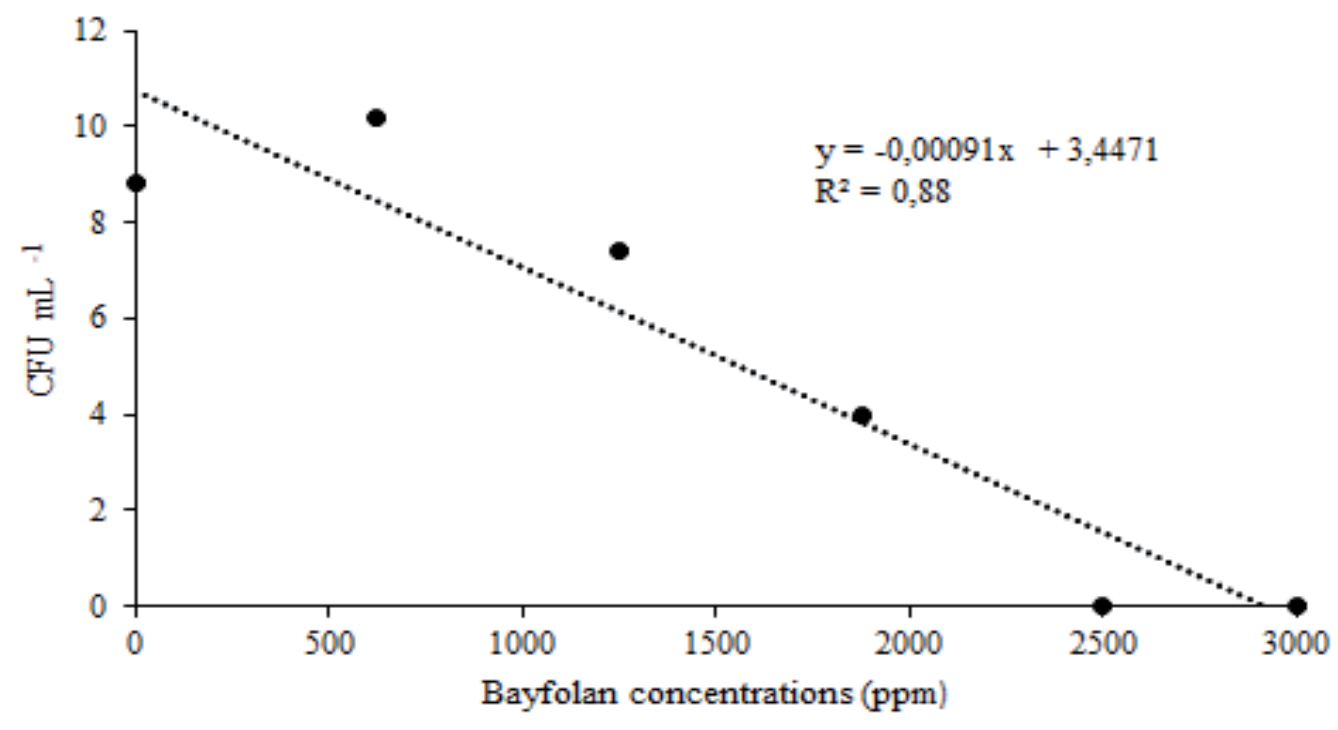

Source: Elaboration of the authors (2018).

For isolate 59 of $P$. syringae pv. garcae (FIGURE 2), at 625 ppm concentration of Bayfolan ${ }^{\circledR}$ Copper, there was virtually no inhibition of bacterial growth when compared to control. At 1.250 ppm concentration of Bayfolan ${ }^{\circledR}$ copper, the number of CFU tended to increase. At a concentration of 1.875 ppm, Bayfolan ${ }^{\circledR}$ copper caused a $40.82 \%$ reduction in the number of colonies. From a concentration of 2.500 ppm on, Bayfolan ${ }^{\circledR}$ copper completely inhibited bacterial growth in vitro. 
Figure 2 - Effect of different concentrations of Bayfolan ${ }^{\circledR}$ copper on the growth of Pseudomonas syringae pv. garcae in vitro, Isolated 59, Muzambinho, 2018. Data transformed for $y=\sqrt{ }(x+0.5)$.

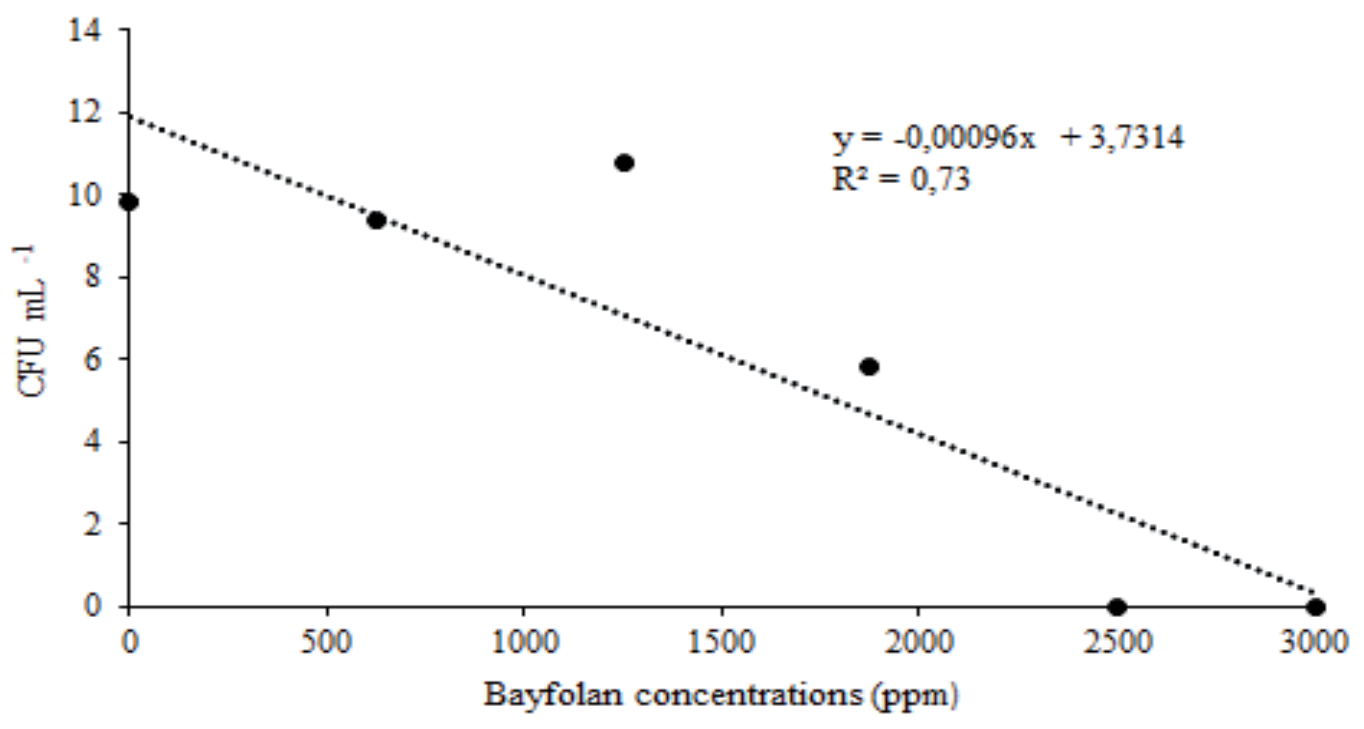

Source: Elaboration of the authors (2018).

Although the behavior of the two isolates, 157 and 59, were similar, isolate 59 presented lower sensitivity to Bayfolan ${ }^{\circledR}$ copper at a concentration of $1.875 \mathrm{ppm}$, with a reduction percentage of $40.82 \%$ and $54.55 \%$ for isolates 59 and 157 , respectively. However, both isolates were completely inhibited with Bayfolan ${ }^{\circledR}$ copper at 2.500 ppm concentration.

The pathogen $P$. syringae pv. garcae is a restricted aerobic gram-negative bacterium (MCDONNELL; RUSSEL, 1999). Based on the concept pointed out by Fisher (2005) that gram-negative bacteria have a cell envelope at which a cell membrane outside the cell wall is composed of an asymmetric lipopolysaccharide-phospholipid bilayer, promoting an effective physical barrier against the entry of molecules into the bacterial cell, it can be inferred that isolate 59 is likely to have a more effective membrane in controlling the entry of Bayfolan ${ }^{\circledR}$ copper.

One factor responsible for the copper's antimicrobial properties is the ability of this metal to accept or donate its electrons easily (PRO COBRE, 2016). This chemical property allows copper ions to alter proteins within microorganism cells so that proteins can no longer perform their normal functions (PRO COBRE, 2016).

Comparing the number of CFU obtained in the treatments that received Bayfolan ${ }^{\circledR}$ copper, the treatment that received the commercial antibiotic Kasumin ${ }^{\circledR}$ and the untreated control, it was found that the treatments differed significantly from each other (Table 1 ). Bayfolan ${ }^{\circledR} \operatorname{copper}_{\text {concentrations }}$ of 2.500 ppm and 3.000 ppm were as effective as Kasumin ${ }^{\circledR}$ chemical treatment in reducing bacterial growth. 
Table 1 - Effect of different concentrations of Bayfolan ${ }^{\circledR}$ copper and Kasumin ${ }^{\circledR}$ antibiotic on growth of two isolates of Pseudomonas syringae pv. garcae in vitro, Muzambinho, 2018.

\begin{tabular}{ccc}
\hline Treatments $(\mathrm{ppm})$ & Isolate 157 (CFU) & Isolate 59 (CFU) \\
\hline 0 & $0 \% \mathrm{a}$ & $0 \% \mathrm{a}$ \\
625 & $0 \% \mathrm{a}$ & $4.1 \% \mathrm{a}$ \\
1250 & $15.9 \% \mathrm{~b}$ & $0 \% \mathrm{a}$ \\
1875 & $54.5 \% \mathrm{c}$ & $40.8 \% \mathrm{~b}$ \\
2500 & $100 \% \mathrm{c}$ & $100 \% \mathrm{c}$ \\
3000 & $100 \% \mathrm{c}$ & $100 \% \mathrm{c}$ \\
Kasumin $^{\circledR}$ & $100 \% \mathrm{c}$ & $100 \% \mathrm{c}$ \\
CV(\%) & 35,29 & 21,08 \\
\hline
\end{tabular}

* In the column, the means followed by the same lowercase letter do not differ from each other by the ScottKnott test at 0.05 significance. Data transformed for $y=\sqrt{ }(x+0.5)$. The data show normality and homogeneity.

Source: Elaboration of the authors (2018).

Yamada (2014), when studying the resistance of $P$. syringae pv. garcae to copper, found that isolates of the pathogen are sensitive to copper sulphate in vitro and that cuprous oxide preventively applied showed greater effectiveness in controlling the aureolated spot in coffee seedlings.

Several studies report the bactericidal effect of copper. Morais et al. (2015) reported that concentrations of copper hydroxide $(0.18 ; 0.36 ; 0.54$ and $0.72 \%)$ and copper phosphite $(0.83 \%)$ completely inhibited the growth of $P$. syringae pv.garcae in vitro.

Domingues et al. (2015), in their research on the chemical and biological control of aureolated leaf spot in coffee seedlings, found that products formulated with copper hydroxide promoted a drastic reduction in the number of CFU of $P$. syringae pv. garcae from $100 \mu \mathrm{g}$ i.a per liter of N.A. medium.

According to Franco and Takatsu (2004), 38 isolates tested from Xanthomonas axonopodis pv. passiflorae (Pereira) Dye showed no resistance to CuSO4 at concentrations of 500 pmm and 1.000 pmm.

In addition to the bactericidal effect of Bayfolan ${ }^{\circledR}$ copper, due to the presence of copper (copper sulphate), amino acids and sulphur in its composition, it can induce resistance in plants by activating their defense mechanisms, as evidenced by Zambolim and Ventura (1996), Igarashi et al. (2010) and Vitti, Otto and Savieto (2015). This is an advantage, since this product is marketed as foliar fertilizer.

\section{Conclusions}

Bayfolan ${ }^{\circledR}$ copper is effective in controlling isolates 157 and 59 of Pseudomonas syringae pv. garcae in vitro from concentration of 2.500 ppm onwards.

Bayfolan ${ }^{\circledR}$ copper at concentrations of 2.500 and 3.000 ppm is as efficient as Kasumin ${ }^{\circledR}$ in controlling bacterial growth. 


\section{Efeito do Bayfolan ${ }^{\circledR}$ cobre no controle de Pseudomonas syringae pv. garcae in vitro}

\section{Resumo}

Um dos fatores limitantes à produção de café é a mancha aureolada causada pela bactéria Pseudomonas syringae pv. garcae. 0 objetivo deste trabalho foi avaliar diferentes concentrações do Bayfolan ${ }^{\circledR}$ cobre no crescimento de dois isolados de $P$. syringae pv. garcae in vitro. Foram utilizados os isolados 157 e 59 de $P$. syringae pv. garcae. Foram instalados dois experimentos, em delineamento inteiramente casualizado (DIC), com 7 tratamentos, 5 repetições, totalizando 35 unidades experimentais. Cada unidade experimental foi constituída por uma placa de petri. Para a instalação do experimento, o Bayfolan ${ }^{\circledR}$ cobre foi adicionado e homogeneizado ao meio de cultura Kado 523, nas seguintes concentrações $0 ; 625 ; 1.250 ; 1.875 ; 2.500$ e 3.000 ppm e como testemunha posi-

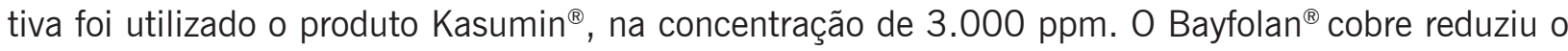
crescimento dos dois isolados avaliados in vitro com o aumento da sua concentração. Nas concentrações de 2.500 e 3.000 ppm, o Bayfolan ${ }^{\circledR}$ cobre inibiu completamente o crescimento de ambos os isolados, similarmente ao tratamento Kasumin ${ }^{\circledR}$. Conclui-se que o Bayfolan ${ }^{\circledR}$ cobre é eficiente no controle de $P$. syringae pv. garcae in vitro a partir da concentração de 2.500 ppm.

Palavras-chave: Bacteriose. Sulfato de cobre. Coffea arabica

\section{References}

AGROFIT. Consulta de ingrediente ativo. Disponível em: <http://agrofit.agricultura.gov.br/agrofit_ cons/principal_agrofit_cons>. Acesso em: 21 jan. 2019.

ALLTECH. Informações ténicas - Soil Set ${ }^{\circledR}$. Disponível em: <https://www.alltech.com/soil-set>. Acesso em: 21 jan. 2019.

AMARAL, J. F.; TEIXEIRA, C. G.; PINHEIRO, E. D. A bacterium causing halo blight of cofee. Arquivos do Instituto Biológico, São Paulo, v. 23, p. 151-155, 1956.

BAYER. Informações técnicas - Bayfolan ${ }^{\circledR}$ cobre . Disponível em: <https://www.agro.bayer.com.br/ produtos/bayfolan>. Acesso em: 08 out. 2017.

BELAN, L. L. Detecção de Pseudomas syringae pv. garcae em sementes, microanálise de raios $\mathrm{X} e$ desenvolvimento de escala diagramática para a mancha areolada do cafeeiro. 2014. 126 f. Tese (Doutorado em/Fitopatologia) - Universidade Federal de Lavras, Lavras, 2014.

CONAB (COMPANHIA NACIONAL DE ABASTECIMENTO). Acompanhamento da safra café. Disponível em: <http://www.conab.gov.br/OlalaCMS/uploads/arquivos/17_09_21_17_00_05_cafe_setembro_2017.pdf>. Acesso: 08 ou 2017.

CRUZ, C.D. Programa GENES. Versão Windows. Viçosa: Universidade Federal de Viçosa, 648 p, 2001. 
DOMINGUES, M. V. P. F.; DEUS, B. C. de; BERIAM, L. O. S.; BRAGHINI, M. T.; ALMEIDA, I. M. G.; BERNADO, E. R. de A.; ARAÚJO, C. F. Q. de; PATRÍCIO, F. R. A. Controle químico e biológico da mancha aureolada em mudas de cafeeiro. In: Simpósio de Pesquisa dos Cafés do Brasil, 9. ,2015, Curitiba. Resumo expandido. Curitiba, 2015.

FRANCO, M. M.; TAKATSU, A. Sensibilidade de Xanthomonas axonopodis pv. passiflorae a cobre. Bioscience Journal, Uberlândia, v. 20, n. 2, p. 207-210, Mai/Ago 2004.

FERREIRA, D. F. Sisvar: um sistema computacional de análise estatística. Ciência e Agrotecnologia, Lavras, v. 35, n. 6, Nov./Dec. 2011.

FISHER, J. F.; MEROUEH, S. O.; MOBASHERY, S. Bacterial resistance to $\beta$-lactam antibiotics: compelling opportunism, compelling opportunity. Chemical Reviews. v. 105, p. 395 - 424, Feb. 2005.

IGARASHI, D.; TAKEDA, T.; NARUSAKA, Y.; TOTSUKA, K. Glutamate fermentation by-product activates plant defense responses and confers resistance against pathogen infection. Journal of Phytopathology, Berlin, v. 158, p. 668-675, 2010.

KADO, C. I.; HESKETT, M. G. Selective media for isolation of Agrobacterium, Corynebacterium, Erwinia, Pseudomonas and Xanthomonas. Phytopathology, v. 60, p. 969-979, 1970.

MALAVOltA, E.; GOMES, F. P.; ALCARDE J. C. Adubos e Adubações. Barueri: Nobel, 2000.

MCDONNELL, G.; RUSSEL, D. Antiseptics and disinfectants: activity, action, and resistance. Clinical Microbiology Reviews, v. 12, p. 147-179, 1999.

MORAIS, O. J. S.; GOULART, R. R.; SANDY, D.; RIBEIRO, N. P. N.; ALMEIDA, B. M.; BELAN, L. L.; POZZA, E. A.; RAIMUNDI, M. K. Controle alternativo da mancha aureolada. In: JORNADA CIENTÍFICA E TECNOLÓGICA DO IFSULDEMINAS, 6., 2014, Pouso Alegre. Resumo. Pouso Alegre: IFSULDEMINAS, 2014.

OLIVEIRA, D. A. M. Proteção do cafeeiro contra a mancha aureolada e análises de enzimas envolvidas no metabolismo fenólico e lignina. 2017. 41 f. Dissertação (Mestrado em Fitopatologia) - Programa de Pós-Graduação, Universidade Federal de Lavras, Lavras, 2017.

OLIVEIRA, J. R.; ROMEIRO, R. S. Reação de folhas novas e velhas de cafeeiros a infecção por Pseudomonas cichorii e P. syringae pv. garcae. Fitopatologia Brasileira, Brasília, v. 15, p. 355-356, 1990.

PATRÍCIO, F. R. A.; ALMEIDA, I. M. G.; BARROS, B. C.; SANTOS, A. S.; FRARE, P. M. Effectiveness of acibenzolar-S-methyl, fungicides and antibiotics for the control of brown eye spot, bacterial blight, brown leaf spot and coffee rust in coffee. Annals of applied biology, v. 152, n. 1, p. 29-39, 2008.

PATRÍCIO, F. R. A. Mancha aureolada volta a preocupar cafeicultores. Boletim Informativo Peracetic. V. 1, 2. ed., 2011. 
PETEK, M. R.; SERA, T.; SERA, G. H.; FONSECA, I. C. B.; ITO, D. S. Seleção de progênies de coffea arabica com resistência simultânea à mancha aureolada e à ferrugem alaranjada. Bragantia, Campinas, v. 65, n. 1, p. 65-73, 2006.

PRO COBRE. Cobre bactericida. Disponível em: <http://www.philomenojr.com.br/downloads/Informacoes/Eluma Conexoes/Cobre antimicrobiano.pdf> . Acesso em: 20 mai 2018.

RODRIGUES, L. M. R.; ALMEIDA, I. M. G. de; PATRÍCIO, F. R. A.; BERIAM, L. O. S.; MACIEL, K. W.; BRAGHINI, M. T.; GUERREIRO FILHO, O. Mancha aureolada do cafeeiro causada por Pseudomonas syringae pv. Garcae. Campinas: Instituto Agronômico, 2013.

SANTOS, L. O.; COSTA, V. S. O.; FREIRE, E. B.; BATISTA, D. C.; TERAO, D.; BARBOSA, M. A. G.Inibição in vitro de Xanthomonas campestris pv viticola por indutores de resistência. In: Embrapa Seminário-Artigo em anais de congresso (ALICE). In: JORNADA DE INICIAÇÃO CIENTÍFICA DA EMBRAPA SEMIÁRIDO, 5., 2010, Petrolina. Anais...Petrolina: Embrapa Semiárido, 2010.

VITTI, G. C.; OTTO, R.; SAVIETO, J. Manejo do enxofre na agricultura. Disponível em: <http://www. ipni.net/publication/ia-brasil.nsf/0/489467390EE9A34B83257F31004B1E61/\$FILE/Jornal152. pdf > . Acesso em: 2 jul. 2018.

YAMADA, J. K. Resistência de isolados de Pseudomonas syringae pv. garcae a cobre. 2014. 50 f. Dissertação (Mestrado em Fitopatologia) - Programa de Pós-Graduação, Universidade Federal de Lavras, Lavras, 2014.

ZAMBOLIM, L.; VENTURA, J. A. Resistência a doenças induzidas pela nutrição das plantas. Piracicaba: POTAFOS, 16 p., 1996.

ZAMBOLIM, L.; VENTURA, J. A. Resistência de doenças induzidas pela nutrição mineral. Revisão Anual de Patologia de Plantas, Passo Fundo, v. 1, p. 275-318, 1993.

Received: July 23, 2018

Accepted: February 6, 2019 